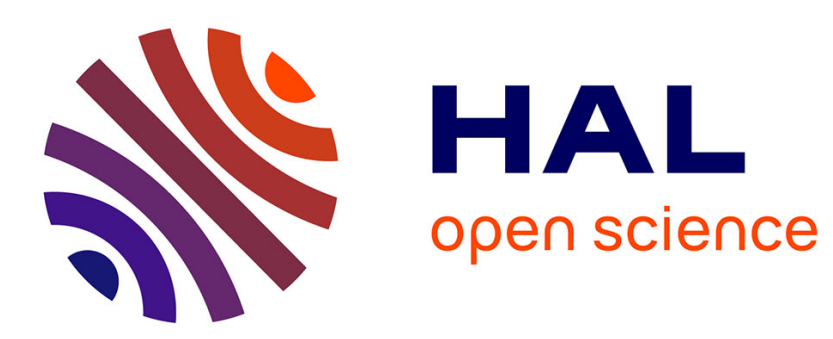

\title{
Plasma membrane of trout spermatozoa: I. Isolation and partial characterization
}

Catherine Labbé, Maurice Loir

\section{To cite this version:}

Catherine Labbé, Maurice Loir. Plasma membrane of trout spermatozoa: I. Isolation and partial characterization. Fish Physiology and Biochemistry, 1991, 9, pp.325-338. 10.1007/BF02265153 . hal-02716127

\section{HAL Id: hal-02716127 \\ https://hal.inrae.fr/hal-02716127}

Submitted on 1 Jun 2020

HAL is a multi-disciplinary open access archive for the deposit and dissemination of scientific research documents, whether they are published or not. The documents may come from teaching and research institutions in France or abroad, or from public or private research centers.
L'archive ouverte pluridisciplinaire HAL, est destinée au dépôt et à la diffusion de documents scientifiques de niveau recherche, publiés ou non, émanant des établissements d'enseignement et de recherche français ou étrangers, des laboratoires publics ou privés. 


\title{
Plasma membrane of trout spermatozoa: I. Isolation and partial characterization
}

\author{
C. Labbé and M. Loir \\ INRA, Physiologie des Poissons, Campus de Beaulieu, 35042 Rennes Cedex, France
}

Accepted: May 3, 1991

Keywords: salmonid, sperm, membrane, nitrogen cavitation, electron microscopy, protein, enzyme, lipid

\begin{abstract}
The plasma membrane from spermatozoa of rainbow trout was isolated by four techniques: sonication, hypotonic shock, mechanical homogenization after freeze-thawing, and nitrogen cavitation, in combination with continuous sucrose gradient centrifugation. Nitrogen cavitation ( $900 \mathrm{PSI}, 20$ min equilibration at $4^{\circ} \mathrm{C}$ ) was the most effective technique.

Following nitrogen cavitation, four bands were recovered in the sucrose gradient at densities $\approx 1.03,1.05$, 1.09 and $1.15 \mathrm{~g} / \mathrm{ml}$. Electron microscopy revealed membrane vesicles of various sizes in bands 1 to 3 , while enzyme analysis revealed a 3.9 to 5.5-fold enrichment in 5 '-nucleotidase and little contamination by lactate dehydrogenase (cytosol) and succinic dehydrogenase (mitochondria). Lipid analysis of bands 1 and 2 indicated a 6107 -fold enrichment in cholesterol and a cholesterol: phospholipid ratio of $0.59-0.70$. Seven classes of phospholipids were present in bands $1-3$ with no significant differences observed among bands. These data indicate that the vesicles (in bands 1 and 2) obtained after nitrogen cavitation are primarily plasma membranes. Membranes in band 3 appear to be slightly contaminated with nuclear membranes.

Most of the plasma membrane proteins were acidic to neutral. The 2 main membrane proteins were 42 and 30 Kilodaltons.
\end{abstract}

\section{Introduction}

The sperm plasma membrane is an important participant in several steps leading to fertilization. However, several of the events preceeding the delivery of the paternal genome into the egg which occur in mammals, do not occur in salmonid fish. There is no epididymal maturation (although changes of the physicochemical parameters of seminal fluid along the genital tract might influence the spermatozoan metabolism in salmonids (Morisawa and Morisawa 1988)), capacitation or acrosome reaction. In salmonids, the critical step for mating success is the initiation and maintenance of sperm motility (Cosson et al. 1989). Flagellar beating is controlled by external $\mathrm{K}^{+}$concentration and by $\mathrm{Ca}^{2+}$ influx through the plasma membrane (Cosson et al. 1989). This suggests that the biochemical and biophysical properties of this cell organelle could influence the ability of fish sperm to fertilize eggs.

When stored in the male genital tract, sperm cells are subjected to large (up to 200 mOsmoles) and rapid changes in osmotic pressure (Maisse et al. 1988; Loir et al. 1990a). The ability of the plasma membrane from trout sperm to resist osmotic shock varies throughout the breeding period and between 
males and is positively correlated with freezing tolerance (Malejac et al. 1990). Properties of the plasma membrane of fish spermatozoa also appear to determine cryopreservation success (Baynes and Scott 1982; Maisse et al. 1988).

Changes in body temperature initiate alterations in the composition of membranes which are responsible for "homeoviscous adaptation". Lipids are the only structural components of membranes modified as a consequence of thermal acclimation (Hazel 1984).

On the other hand, the distribution of fatty acids in the total lipid of trout sperm is greatly affected by diet (Watanabe et al. 1984). According to Baynes and Scott (1982), both the fatty acid composition and fertilizing capacity after cryopreservation differ between trout fed two different diets.

Our laboratory has taken the approach that detailed studies of 1) the molecular composition of the sperm surface, and 2) alterations induced by thermal adaptation and diet, would lead to an understanding of the mechanisms which are involved in the maintenance of motility and the freezing ability of salmonid spermatozoa. Before such studies can be attempted, it is necessary to develop a method for the isolation of plasma membranes in a highly purified form. Several methods have been used to detach the plasma membrane of sperm cells (McNamee 1989), including sonication, mechanical homogenization, hypotonic shock, and nitrogen cavitation. According to Gillis et al (1978), the latter technique is the most effective. While our study was in progress, Lou et al. (1990) opted to prepare plasma membranes from salmon sperm by sonication. In this report, 1) preliminary experiments were carried out to identify the most suitable method of plasma membrane preparation from trout spermatozoa, and 2) we describe the nitrogen cavitation procedure we developed. Membrane preparations were characterized using electron microscopy, phospholipid analysis, marker enzyme analysis and electrophoretic analysis of proteins.

\section{Materials and methods}

Semen was collected throughout the spawning period, by hand stripping, from 1 to 3 year-old mature autumn-spawning and spring-spawning males of rainbow trout kept at $12-15^{\circ} \mathrm{C}$ in recycled freshwater, under natural photoperiod. Care was taken to avoid contamination by blood and feces (Maisse et al. 1988). Semen was stored on ice. Testicular sperm was collected in the following way. Testes were removed (after males had been anesthetized with $0.3 \%$ phenoxyethanol and killed by a blow to the head) and cut into pieces in seminal fluid mineral medium (SFMM, Billard and Jalabert 1974). The suspension was filtered through $150 \mu \mathrm{m}$ nylon filters, then stored on ice.

All the following operations were carried out at $1-4^{\circ} \mathrm{C}$.

\section{Plasma membrane isolation using nitrogen cavitation}

Semen or a sperm suspension obtained from several males, was centrifuged at $500 \mathrm{~g}$ for $15 \mathrm{~min}$, followed by $1000 \times \mathrm{g}$ for $5 \mathrm{~min}$. These conditions affected neither sperm motility nor morphology (Loir, unpublished results). Spermatozoa were resuspended (5 to $10 \times 10^{9}$ cells $/ \mathrm{ml}$ ) in $0.25 \mathrm{M}$ sucrose in $\mathrm{TM}$ buffer $(20 \mathrm{mM}$ Tris- $\mathrm{HCl}$ buffer $\mathrm{pH} 7.8,3 \mathrm{mM}$ $\mathrm{MgCl}_{2}, 1 \mathrm{mM}$ PMSF, $20 \mu \mathrm{g}$ Soybean Trypsin inhibitor $/ \mathrm{ml}, 0.1 \mu \mathrm{g}$ pepstatin $/ \mathrm{ml}$ ). Thirty $\mathrm{ml}$ of sperm suspension was then submitted to nitrogen cavitation in a Parr cell disruption bomb (ref. 4639) packed in ice. Routinely, the cells were pressurized to $900 \mathrm{lb} / \mathrm{in}^{2}$ (PSI; 62 bars) during a $20 \mathrm{~min}$ period, with continuous magnetic stirring. The cavitate was next homogenized by gentle strokes of a glass Dounce homogenizer. The homogenate was then layered over a 0.65 volume of $1 \mathrm{M}$ sucrose in TM buffer, and centrifuged at $500 \times \mathrm{g}$ for $15 \mathrm{~min}$ followed by $1000 \mathrm{~g}$ for $5 \mathrm{~min}$. The crude membrane fraction above the sucrose cushion was collected. Twenty $\mathrm{ml}$ of the crude preparation was next layered over $19 \mathrm{ml}$ of a $0.25-1.8 \mathrm{M}$ sucrose gradient. The gradients were made up in 9 steps $(0.25$, $0.375,0.5,0.75,1$ and $1.2 \mathrm{M}: 2.5 \mathrm{ml} ; 1.4,1.6$ and $1.8 \mathrm{M}: 1.5 \mathrm{ml}$ ) and rendered nearly continuous by storage for $20 \mathrm{~h}$ at room temperature. After centrifugation at $54,000 \times \mathrm{g}$ for $2 \mathrm{~h}$ (SW28 rotor, Beckman L8-55 ultracentrifuge), 4 bands were con- 
sistently visible, at mean densities of $1.03 \mathrm{~g} / \mathrm{ml}$ (Band 1), $1.05 \mathrm{~g} / \mathrm{ml}$ (Band 2), $1.09 \mathrm{~g} / \mathrm{ml}$ (Band 3) and $1.15 \mathrm{~g} / \mathrm{ml}$ (Band 4). Bands were carefully removed (with a syringe and a bent needle), diluted 3-fold with TM buffer, and centrifuged at 100,000 $\mathrm{g}$ for $30 \mathrm{~min}$. Pellets were suspended in $0.25 \mathrm{M}$ sucrose in TM buffer (1-2 $\mathrm{mg}$ protein $/ \mathrm{ml})$ and either used immediately or stored at $-70^{\circ} \mathrm{C}$.

\section{Membrane isolation by sonication}

After resuspension (1.5 to $\left.3 \times 10^{9} \mathrm{cells} / \mathrm{ml}\right)$ in SFMM pH 7.5, $1 \mathrm{mM}$ PMSF, spermatozoa were sonicated in an ice-bath, 2 to 6 times for $30 \mathrm{sec}$ (with $15 \mathrm{sec}$ between treatments), using an MSE $150 \mathrm{~W}$ ultrasonic desintegrator at maximum power. Most of the nuclei and some (unbroken) flagella were removed by centrifugation $(1,000 \times \mathrm{g}, 15 \mathrm{~min})$. Sucrose was then added to a final concentration of $0.25 \mathrm{M}$, and the suspension was centrifuged through $0.375-1.8 \mathrm{M}$ sucrose gradients, as indicated above.

\section{Membrane isolation using hypotonic treatment}

Washed and pelleted spermatozoa were resuspended in 20 volumes of $5 \mathrm{mM}$ Tris- $\mathrm{HCl}$ buffer $\mathrm{pH}$ 8, $1 \mathrm{mM}$ PMSF $\left(1 \times 10^{9}\right.$ cells $/ \mathrm{ml}$ as a mean $)$ for 15 min. Following centrifugation $(1,000 \times \mathrm{g}, 20 \mathrm{~min})$, the pellet was resuspended and homogenized by several strokes of a glass Dounce homogenizer. Sucrose was then added $(0.25 \mathrm{M}$ final concentration) and nuclei and flagellae were partly removed by centrifugation $(1,000 \times \mathrm{g}, 15 \mathrm{~min})$. The suspension was then applied to sucrose gradients as above.

\section{Membrane isolation by freeze-thawing}

Washed spermatozoa resuspended in TM buffer were frozen at $-70^{\circ} \mathrm{C}$. Slow thawing was carried out by storage overnight at $4^{\circ} \mathrm{C}$. After addition of sucrose $(0.25 \mathrm{M}$ final concentration) the suspension was homogenized by several strokes of a glass homogenizer and treated as described above for nitrogen cavitation.

Extraction of membrane proteins with $\mathrm{Na}$ deoxycholate

Membrane proteins were extracted according to Loir et al. (1990). Briefly, washed spermatozoa or fractions were treated for at least $45 \mathrm{~min}$ with $0.2 \%$ $\mathrm{Na}$ deoxycholate in $5 \mathrm{mM}$ Hepes buffer $\mathrm{pH} 8$. After centrifugation $(1,000 \times \mathrm{g}, 20 \mathrm{~min})$, proteins were precipitated from the supernatant by mixing with 9 volumes of ethanol. After sitting overnight at $-20^{\circ} \mathrm{C}$, proteins were collected by centrifugation $(15,000 \times \mathrm{g}, 15 \mathrm{~min})$.

\section{Electron microscopy}

Membrane material (obtained at the different steps after disruption of sperm cells by nitrogen cavitation and material obtained after sonication and hypotonic treatment) was pelleted by centrifugation, resuspended in 4\% glutaraldehyde (in phosphate buffer, $\mathrm{pH} 7.5$ ), washed in $0.2 \mathrm{M}$ cacodylate buffer $\mathrm{pH} 7.4$, and, finally post-fixed for $1 \mathrm{~h}$ in $1 \%$ osmium tetroxide (in cacodylate buffer containing $1.5 \%$ potassium ferricyanide). The material was embedded in $2 \%$ agar, dehydrated in acetone, and then embedded in Epon-Araldite. Sections were double-stained and observed with a Philips CM12 electron microscope.

\section{Polyacrylamide gel electrophoresis}

SDS-polyacrylamide slab gel electrophoresis was performed according to Laemmli (1970) on 6-16\% gradient gels. Pelleted material obtained at various steps of membrane isolation was resuspended either in sample buffer $(0.062 \mathrm{M}$ Tris- $\mathrm{HCl}, \mathrm{pH} 6.8,2 \%$ sodium dodecyl sulfate, $10 \%$ glycerol and $5 \% \beta$ mercaptoethanol) or in $0.2 \% \mathrm{Na}$ deoxycholate. Proteins solubilised by deoxycholate were precipitated by ethanol (see above) and then resuspended in sample buffer. Before loading, all samples were 
boiled for $5 \mathrm{~min}$. Proteins were stained with $0.2 \%$ $\mathrm{R} 250$ Coomassie blue. Gels were scanned in a Vernon PHI5 densitometer.

Membrane proteins were also analysed by twodimensional electrophoresis according to Dacheux et al. (1989). Briefly, the isoelectric focusing (IEF) separation was carried out according to O'Farrell (1975) in the presence of ampholytes $(2-11 \mathrm{pH})$. The second-dimension electrophoresis was identical to the $1 \mathrm{D}$ system. The proteins were detected by silver staining according to Damerval et al. (1986).

\section{Enzyme assays}

Three enzymes were assayed in the membrane fractions. The method of Michell and Hawthorne (1965) was used for the determination of 5'-nucleotidase (EC 3.1.3.5; plasma-membrane marker) with the following modification. Fractions were incubated with $100 \mathrm{mM}$ sodium glycerol 2-phosphate (phosphatase activities were saturated by this concentration), and either in the presence or absence of $5 \mathrm{mM}$ adenosine 5'-monophosphate. The 5'-nucleotidase activity was estimated by the difference between the two values obtained. The incubation time was $1 \mathrm{~h}$. All necessary controls were carried out. The amount of phosphate released was determined according to Lanzetta el al. (1979). Succinic dehydrogenase (EC 1.3.99.1; mitochondrial marker) was determined according to Green et al. (1955). Lactate dehydrogenase (EC 1.1.1.27; cytosolic marker) activity was determined using Boehringer kit (ref. 543039), after adaptation, to carry out multiple assays in 96-well plates, using a standard plate reader.

\section{Lipid analysis}

Lipids from sperm homogenates and from various sperm fractions obtained after cavitation were extracted according to Folch et al. (1957). The chloroform/methanol mixture $(2: 1, \mathrm{v} / \mathrm{v})$ contained $0.02 \%$ Butyl Hydroxytoluene (BHT). The lower phase was carefully separated, dried and dissolved in 2-propanol. Total cholesterol was determined after lipids were extracted, by an enzymatic method (Biochemica test combination, Boehringer) adapted to carry out assays in 96-well plates. Phospholipid phosphorus was determined after hydrolysis with sulfuric acid according to Bartlett (1959). Total phospholipid was calculated from the inorganic phosphate and expressed as $\mu \mathrm{mol}$ phosphate/mg protein. Phospholipids were collected according to Juaneda and Rocquelin (1985), the dried lower phase being dissolved in $0.5 \mathrm{ml}$ chloroform then fractionated on Sep-Pak silica columns (Waters associates). Phospholipid classes were visualised by thin-layer chromatography (TLC) on silica gel plates (Merck, ref. 5626) in chloroform/ methanol/acetic acid/petroleum ether $(40 / 20 / 10 /$ $30, \mathrm{v} / \mathrm{v})$ plus $1.8 \%(\mathrm{w} / \mathrm{v})$ boric acid. Lipid bands were located using iodine vapor. Identification of the bands was by comparison to reference phospholipids (purchased from Sigma). Phospholipid classes were separated by high performance liquid chromatography (HPLC) using a Zorbax silica column ( $250 \mathrm{~mm}$ length, $4.6 \mathrm{~mm}$ internal diameter, $5 \mu \mathrm{m}$ particle size) and an hexane/isopropanol/ water solvant $(3 / 2 / .125$ to $.250, \mathrm{~V} / \mathrm{V})$. Phospholipids were assayed according to Bartlett (1959).

\section{Other methods}

Protein was usually determined according to Lowry et al. (1951). However, because of the interference of several molecules used, the method of Smith et al. (1985), using Pierce "BCA protein assay reagent" kit, was preferred for protein determinations related to lipid analysis. In both cases, bovine serum albumin was used as a standard. The mean difference between protein concentration values obtained for 22 samples by the 2 methods was equal to $\pm 5.8 \%$ of the mean value.

\section{Results}

Comparison of four methods for cell fractionation

Efficiency of sonication appeared to depend on the sperm concentration, the volume treated, and the 

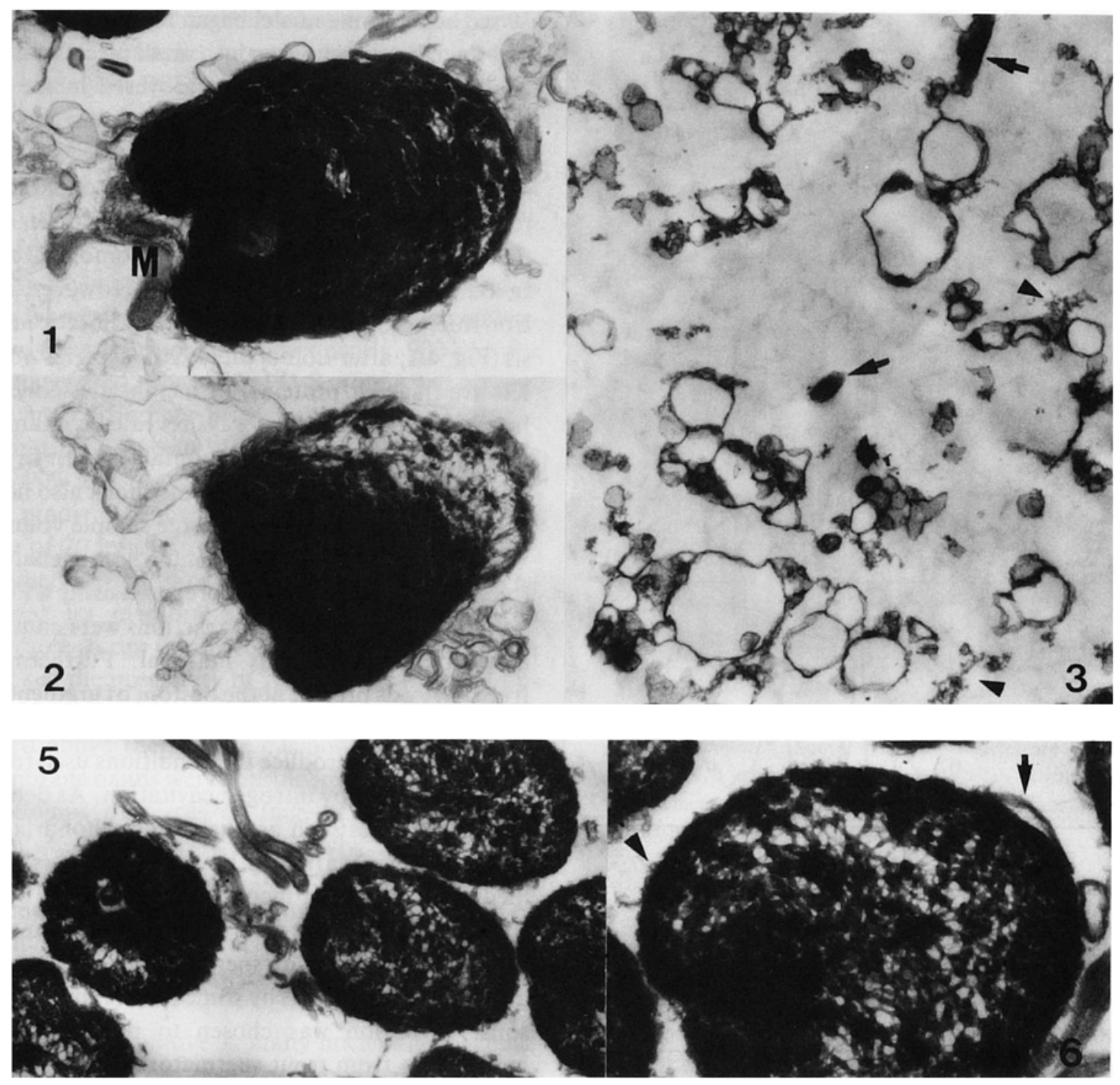

Fig. 1. A sperm head after sonication twice for 30 seconds. Plasma and nuclear membranes are only partly detached and chromatin is unchanged. M: mitochondria $(\times 24,200)$.

Fig. 2. A sperm head after sonication 6 times for 30 seconds. Chromatin is decondensed and begins to disperse $(\times 24,200)$.

Fig. 3. Membrane fraction collected from sucrose gradient $(\mathrm{d}=1.06 \mathrm{~g} / \mathrm{ml})$ after detachment by hypotonic treatment. Arrows: pieces of flagella. Arrowheads: non membranous material $(\times 15,500)$.

Fig. 5. Sperm heads and flagellae in the homogenate obtained after nitrogen cavitation. Most of these organelles are devoid of plasma membrane $(\times 14,200)$.

Fig. 6. Detail of a sperm head after nitrogen cavitation. Pieces of plasma membrane (short arrow) still adhere to the head. The nuclear membrane is hardly visible. Small membranous blebs (arrowhead) could correspond to the external layer of the nuclear membrane $(\times 31,200)$.

geometry of the vessel, in addition to the power and frequency employed. The optimal duration time of sonication was difficult to determine. For instance, electron microscopy revealed that the plasma membrane was detached only partly from nuclei and flagellae by two $30 \mathrm{sec}$ bursts (Fig. 1), while after six 

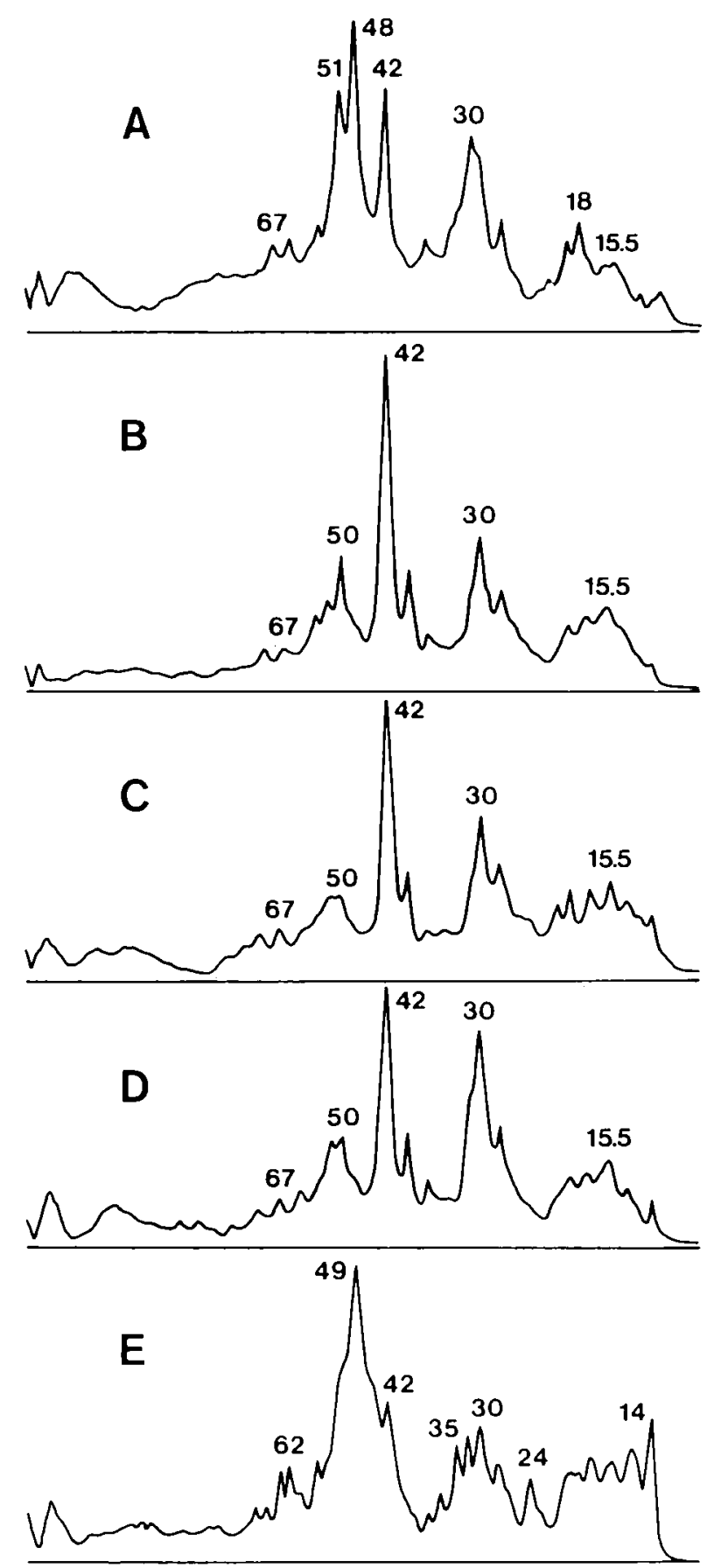

Fig. 4. Electrophoregrams (SDS gels) of proteins extracted from membrane vesicles obtained, A: after hypotonic treatment (protein $48 \mathrm{KD}$ reveals flagellar contamination); $\mathrm{B}$ : after nitrogen cavitation, in band $1 ; \mathrm{C}$ : idem, in band $2 ; \mathrm{D}$ : idem, in band 3 . E: proteins extracted from material obtained after nitrogen cavitation in band 4; proteins $24,35,48-49$ (tubulin) and $62 \mathrm{KD}$ correspond to the major flagellar proteins (Loir et al. 1990). Molecular weights of proteins are indicated in KD.
$30 \mathrm{sec}$ bursts some nuclei began to disperse (Fig. 2) and flagellae were broken into small pieces or disorganised so that membranes recovered in the gradient were contaminated by amorphous material and flagellar fragments.

Trout sperm subjected to hypotonic shock released large membrane ghosts which often contained a coiled flagellum. Potter homogenization favoured the removal of flagellae. However, electron microscopy (Fig. 3) and electrophoretic analysis (Fig. 4A; after Loir et al. (1990), proteins 48-51 $\mathrm{KD}$ are flagellar proteins) of membranes collected from sucrose gradients always revealed contamination by flagellae and other material (Fig. 3). In contrast to other methods, hypotonic shock also necessitated the centrifugation of large sample volumes.

Floculate material was present in homogenates of freeze-thawed spermatozoa prepared using a Potter homogenizer, and gradient fractions were contaminated by heterogeneous material. Furthermore, free DNA was present at the bottom of gradients indicating that nuclei had been destroyed.

It is easy to reproduce the conditions used to disrupt sperm cells by nitrogen cavitation. As detailed later, organelles such as nuclei, mitochondria and flagellae were unaffected by cavitation in isotonic medium while being inconstantly disrupted by the sonication and freeze-thawing techniques. In addition, large amounts of sperm can be processed in about the same time as by sonication. For these reasons, cavitation was chosen to prepare plasma membranes from trout spermatozoa.

\section{Cell fractionation by nitrogen cavitation}

To determine the optimal conditions for the disruption of sperm cells, we considered 1) the yield of deoxycholate-soluble (D-S) protein released into the supernatant collected above the sucrose cushion and 2) the yield of D-S protein collected from the gradient in bands 1 to 3 , compared to the amount present in the cavitate.

The yields of D-S protein were not conspicuously different whether sperm cells were disrupted in hypotonic medium (TM buffer) or in $0.25 \mathrm{M}$ sucrose in TM buffer. Thus, isotonic medium, which 
minimised nuclear and mitochondrial damage, was retained. The applied pressure was varied between 600 and 1100 PSI. The yield of D-S protein obtained in the supernatant after cavitation at $600 \mathrm{PSI}$ was lower $(30-32 \%)$ than at 800 to 1100 PSI $(35-46 \%)$. The yield of D-S protein after gradient centrifugation was $8.5-23 \%$ for $600 \mathrm{PSI}, 18-26 \%$ for $800-850$ PSI and $6-18.5 \%$ for 1100 PSI. Furthermore, when the pressure was 600 PSI, bands 2 and 3 were contaminated by only partly demembranated pieces of flagella. Consequently, 900 PSI was routinely used. The yield of D-S protein was not significantly different whether cavitation was for 20 or $40 \mathrm{~min}$ : $38-43 \%$ and $18-20 \%$ after $20 \mathrm{~min}$ versus $45-46 \%$ and $19-20 \%$ after $40 \mathrm{~min}$, in supernatant and gradient bands respectively. Thus, the shorter time of $20 \mathrm{~min}$ was retained.

When numerous or large sperm samples are to be treated for membrane preparation, it would be desirable to run the sucrose gradients later. So, we checked the possibility of freezing the material obtained after cavitation. When the suspension collected above the sucrose cushion was frozen, the membrane bands were conspicuously contaminated by clumps of pieces of flagella aggregated with membranous material. Conversely, when the cavitate was frozen, then thawed and centrifuged through a $1 \mathrm{M}$ sucrose cushion, the composition of the membrane bands obtained at subsequent steps appeared to be similar to those obtained without freezing.

In order to remove as many nuclei and flagellae as possible before gradient centrifugation, three procedures were tried. 1) the cavitate was centrifuged at $500 \times \mathrm{g}$ for $20 \mathrm{~min}$; 2) the sucrose concentration of the cavitate was raised to $1.2 \mathrm{M}$ prior to centrifugation at $500 \times \mathrm{g}$ for $20 \mathrm{~min}$ followed by $2,000 \times \mathrm{g}$ for $10 \mathrm{~min} ; 3$ ) the cavitate was centrifuged through a sucrose cushion (see Material and Methods). Whereas only $26 \%$ of the D-S protein was retrieved in the supernatant with the first method, $40-42 \%$ was retrieved with the 2 others. Electrophoresis and phase contrast microscopy were employed to show that the purity of the membrane fractions collected from the gradients was similar with the 3 techniques. Because it was easier to work with sucrose cushions, this method was routinely used.

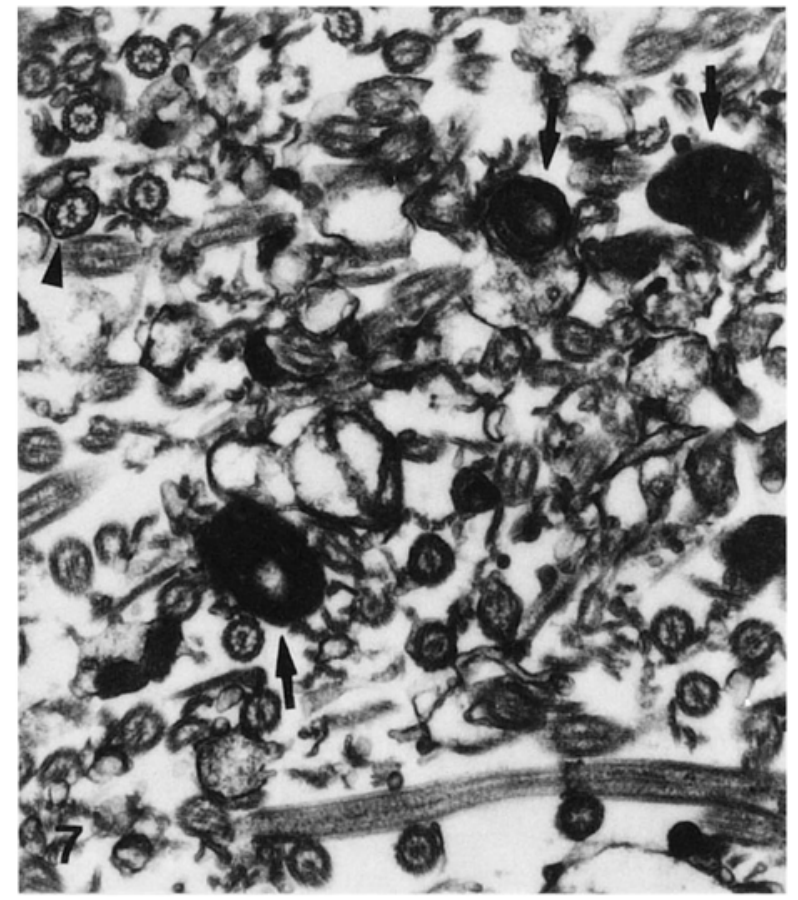

Fig. 7. Material collected in band 4 in sucrose gradient after nitrogen cavitation. Some membrane vesicles are mixed with mitochondria (arrows) and pieces of flagellae, mostly devoid of plasma membrane. Arrowhead: section of flagellum surrounded by plasma membrane $(\times 24,200)$.

\section{Morphological analysis}

Electron microscopic analysis of the homogenate obtained after cavitation and homogenization revealed the following points. 1) Most of the flagella were detached from the heads. 2) About 80-95\% of the flagellar membrane was detached (Figs. 5 and 7). 3) The classic organisation of the flagellar tubules was disrupted only in certain flagellae. 4) While in all the nuclei, the central chromatin was somewhat less compact than in untreated spermatozoa, the peripheral chromatin layer remained compact and homogeneous, displaying no sign of dispersion (Fig. 6). 5) Roughly $80-95 \%$ of the plasma membrane was removed from the heads. 6) Although it was difficult to distinguish the nuclear membrane, it seemed that at least $10-20 \%$ were unbroken and that an inestimable amount of the nuclear membrane, or of only its external layer, was broken into small vesicles either still adhering to the 


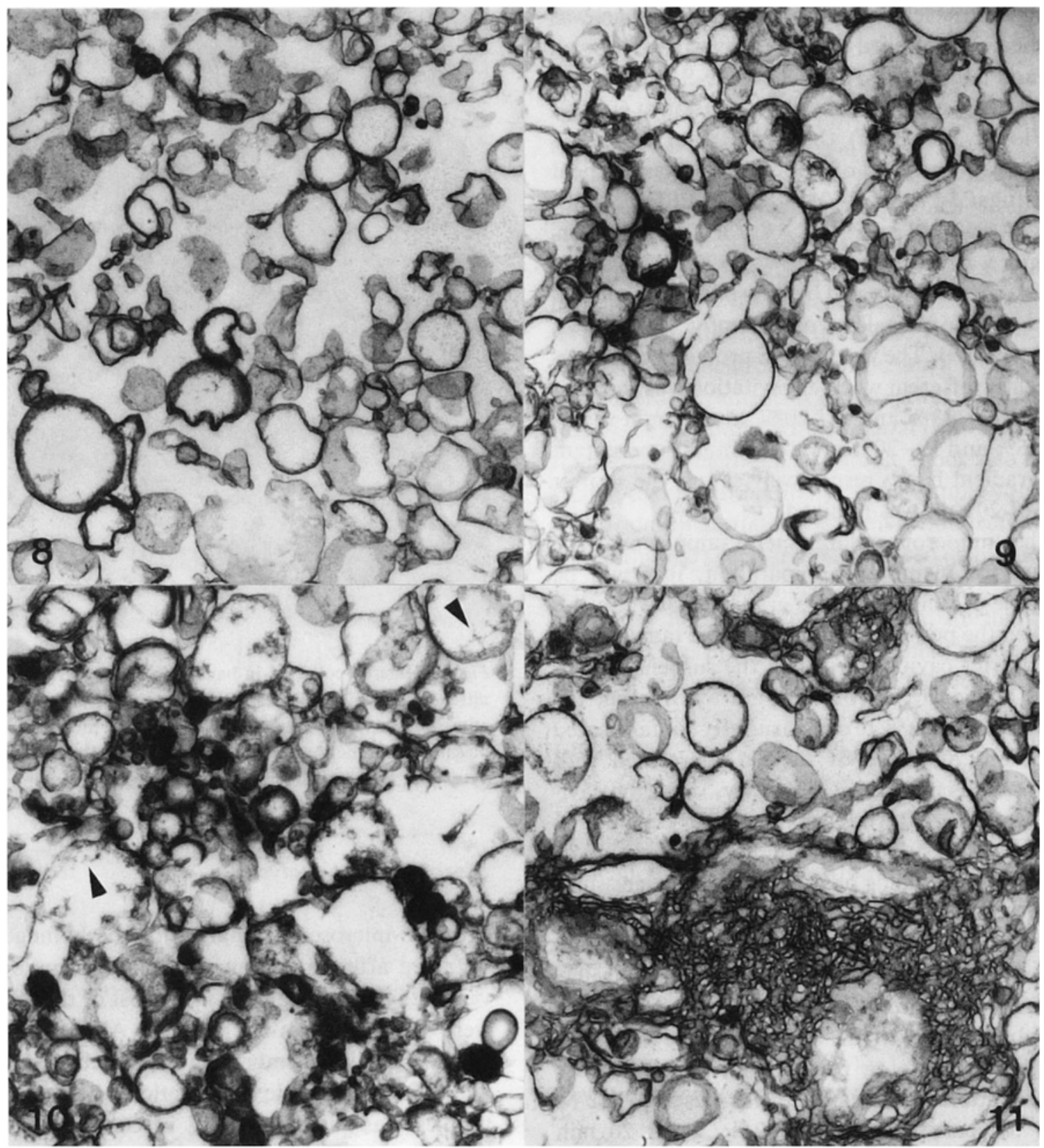

Fig. 8, 9, 10 and 11 . Electron micrographs $(\times 24,200)$ of membranes obtained after nitrogen cavitation in, 8: band 1, 9 and 11: band 2, 10: band 3 . In band 3, fibrous material (arrowheads) is attached to the inner side of vesicles. Two clusters of membrane sheets are shown in Fig. 11.

nuclei or not (Fig. 6). 7) All the mitochondria were detached from the heads.

Electron microscopy confirmed that the supernatant collected above the sucrose cushion contained flagellae mixed with membranous material and no nuclei.
Bands $1(\mathrm{~d} \approx 1.03 \mathrm{~g} / \mathrm{ml}), 2(\approx 1.05 \mathrm{~g} / \mathrm{ml})$ and 3 $(\approx 1.09 \mathrm{~g} / \mathrm{ml})$ contained smooth vesicles of heterogeneous size $(0.12-0.9 \mu \mathrm{m}$ in diameter in band 1 and $0.15-0.75 \mu \mathrm{m}$ in bands 2 and 3) and some membrane sheets (Figs. 8-10). At high magnification, orthogonal sections revealed the typical 
Tahle 1. Specific activities of enzymes in cavitated trout spermatozoa and in sucrose gradient fractions

\begin{tabular}{|c|c|c|c|c|c|}
\hline & Homogenate & B! & B2 & B3 & B4 \\
\hline $\begin{array}{l}\text { Protein } \\
m g / 10^{10} \text { spzoa. }\end{array}$ & $\begin{array}{c}12.4 \pm 1.9 \\
(n=16)\end{array}$ & $\begin{array}{c}.068 \pm .034 \\
(n=18)\end{array}$ & $\begin{array}{c}.069 \pm .020 \\
(n=18)\end{array}$ & $\begin{array}{c}.113 \pm .059 \\
(n=18)\end{array}$ & $\begin{array}{c}.406 \pm .222 \\
(n=4)\end{array}$ \\
\hline $\begin{array}{l}\text { 5'-nucleotidase } \\
\qquad(\mathrm{n}=3) \\
\text { nmoles } \mathrm{P} / \mathrm{min} / \mathrm{mg}\end{array}$ & $1.02 \pm .17$ & $\begin{array}{c}4.16 \pm .35 \\
(\times 4.1)\end{array}$ & $\begin{array}{c}5.64 \pm .61 \\
(\times 5.5)\end{array}$ & $\begin{array}{c}3.95 \pm 1.26 \\
(\times 3.9)\end{array}$ & $1.68 \pm .42$ \\
\hline $\begin{array}{l}\mathrm{SDH}(\mathrm{n}=2) \\
\mathrm{nmoles} / \mathrm{min} / \mathrm{mg}\end{array}$ & $475 \pm 145$ & & $<75$ & & $\begin{array}{c}1609 \pm 1209 \\
(\times 3.4)\end{array}$ \\
\hline $\begin{array}{l}\text { L.DH }(n=3) \\
\text { U/mg protein }\end{array}$ & $297 \pm 120$ & & $84 \pm 40$ & & $53 \pm 23$ \\
\hline
\end{tabular}

Data are shown as Mean \pm SD (number of experiments); at least 7 males were used for each experiment.

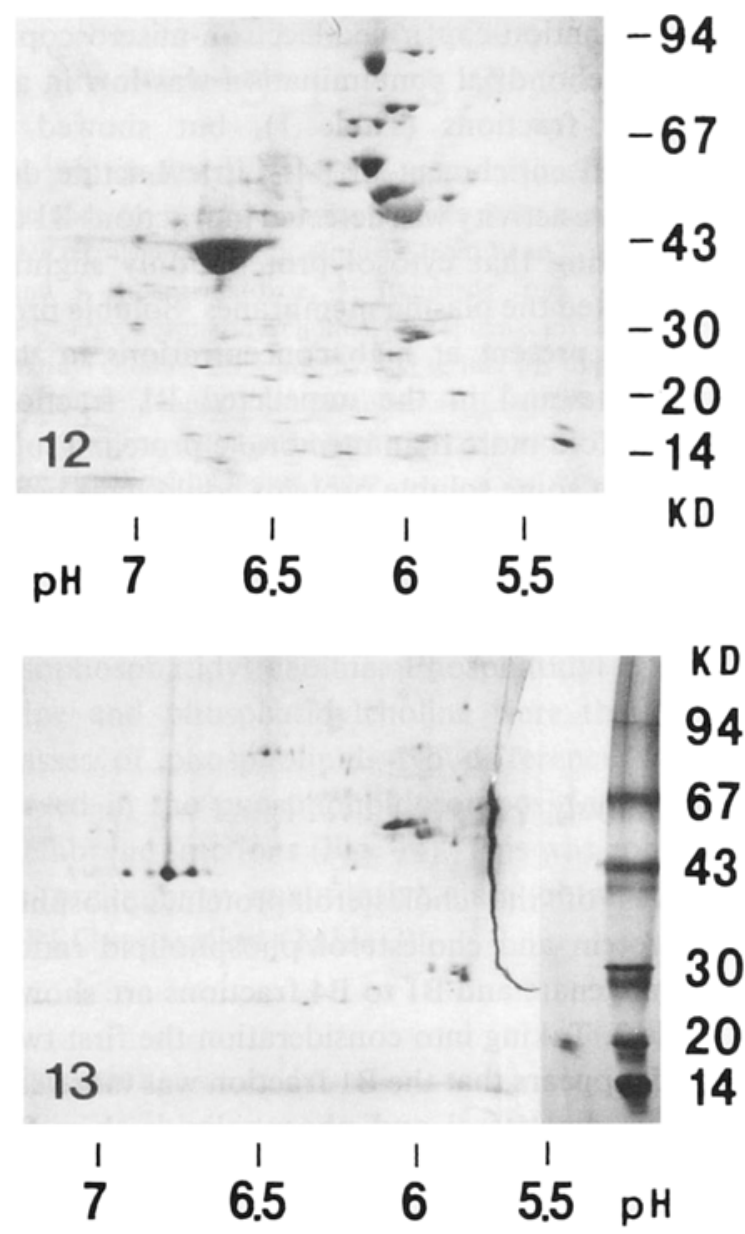

Fig. 12 and 13. Two-dimensional electrophoresis of proteins, 12: extracted from spermatozoa by $\mathrm{Na}$ deoxycholate and 13: from membrane vesicles obtained in band 1 after nitrogen cavitation. Right: standard molecular weights. trilaminar structure of biological membranes. Most of the vesicles present in fractions 1 and 2 did not contain electron-dense material. In band 3 (Fig. 10) and also in band 4 (Fig. 7), some vesicles showed a somewhat fibrous material adhering to the inner side of the membrane. Neither microtubules nor mitochondria were seen in fractions 1 to 3 . In these 3 bands, some structures $(0.4-2 \mu \mathrm{m}$ mean diameter) composed of tightly packed membrane sheets (Fig. 11) were present while a very low proportion of vesicles were constituted of several concentrically-arranged membrane layers. Band 4 (Fig. 7) consisted of some membrane vesicles mixed with pieces of flagellae, some dispersed microtubules, well-preserved mitochondria and some amorphous material.

\section{Protein analysis}

After cavitation and centrifugation through a $1 \mathrm{M}$ sucrose cushion, 35 to $39 \%(n=3)$ of the total proteins present in the cavitate were retrieved in the suspension collected above the cushion. The relative amount of membrane protein present in bands 1,2 and 3 was variable. The total recovery of sperm membrane proteins in the 3 bands varied around $2 \%$ (Table 1), i.e., a mean of $250 \mu \mathrm{g}$ membrane protein was obtained from $10^{10}$ spermatozoa. The yield could be improved (no quantitative estimation) by re-treating the material which had both 
Table 2. Cholesterol and phospholipid content of cavitated trout spermatozoa and sucrose gradient fractions

\begin{tabular}{lcccc}
\hline & $\begin{array}{c}\text { Homogenate } \\
(\mathrm{n}=3)\end{array}$ & $\begin{array}{c}\mathrm{B} 1 \\
(\mathrm{n}=3)\end{array}$ & $\begin{array}{c}\mathrm{B} 2 \\
(\mathrm{n}=5)\end{array}$ & $\begin{array}{c}\text { B3 } \\
(\mathrm{n}=4)\end{array}$ \\
\hline $\begin{array}{l}\text { Chol./Prot. } \\
\text { (nmoles/mg) }\end{array}$ & $165 \pm 67$ & $\begin{array}{c}1134 \pm 598 \\
(\times 6.9)\end{array}$ & $\begin{array}{c}1041 \pm 571 \\
(\times 6.3)\end{array}$ & $\begin{array}{c}573 \pm 144 \\
(\times 3.5)\end{array}$ \\
$\begin{array}{l}\text { Phosp./Prot. } \\
\text { (nmoles/mg) }\end{array}$ & $354 \pm 98$ & $\begin{array}{c}1920 \pm 264 \\
(\times 5.4)\end{array}$ & $\begin{array}{c}1480 \pm 382 \\
(\times 4.2)\end{array}$ & $840 \pm 276$ \\
$(\times 2.4)$ & $609 \pm 109$ \\
Chol./Phosp. & $.47 \pm .08$ & $.59 \pm .19$ & $.70 \pm .23$ & $.68 \pm .29$ \\
\hline
\end{tabular}

Data are shown as Mean \pm SD (number of experiments); at least 7 males were used for each experiment.

centrifuged into the sucrose cushion and pelleted under the cushion. The purity of the membrane fractions so obtained was similar to that obtained by the original procedure.

SDS-PAGE analysis revealed that membrane proteins and molecular weights ranging between 10.5 and $110 \mathrm{KD}$. The predominant proteins were 42 and $30 \mathrm{KD}$. Protein patterns were similar for fractions B1, B2 and B3 (Fig. 4). However, there was a tendency for the relative amount of 11-22 $\mathrm{KD}$ and especially $26-32 \mathrm{KD}$ proteins to increase from $\mathrm{B} 1$ to $\mathrm{B} 3$, as compared to the $42 \mathrm{KD}$ protein (Fig. 4B,C,D).

Membrane proteins were also present in $\mathrm{B} 4$, but they were mixed with proteins characteristic of flagellae, especially the main flagellar protein of 49 $\mathrm{KD}$ (Loir et al. 1990b), which predominated in this fraction (Fig. 4E). A similar pattern was observed in material obtained from the sucrose cushion.

Two-dimensional electrophoresis of membrane proteins from bands $1-3$ revealed the presence of more than 50 proteins, the majority of which were acidic to neutral (Fig. 13). All of these proteins were also present in deoxycholate extracts of total washed spermatozoa, which also contained numerous additional proteins (Fig. 12). Several charge variants of apparently singular proteins were observed. Two minor proteins streaked across the gel map, suggesting they might be glycoproteins.

\section{Enzyme analysis}

Subcellular fractions were assayed for 5'-nucleotidase (Table 1). Specific activity of this enzyme was
3.9 to 5.5 -fold greater in bands $1-3$ than obtained in the homogenate. Measurements of succinic dehydrogenase activity, as a marker for mitochondrial contamination confirmed electron-miscroscopic data: mitochondrial contamination was low in all membrane fractions (Table 1), but showed a pronounced enrichment in B4. Little Lactate dehydrogenase activity was detected in fractions $\mathrm{B} 1$ to B3 suggesting that cytosol proteins only slightly contaminated the plasma membranes. Soluble proteins were present at high concentrations in the homogenate and in the unpelleted $\mathrm{B} 1$ fraction (about 30 fold more than membrane proteins) suggesting that some soluble proteins could have been trapped within membrane vesicles. However, sonication of the $\mathrm{B} 1$ fraction prior to pelleting the membranes, did not change significantly the protein pattern.

\section{Lipid analysis}

Estimates of the cholesterol/protein, phospholipid/protein and cholesterol/phospholipid ratios for homogenate and B1 to B4 fractions are shown in Table 2. Taking into consideration the first two ratios, it appears that the $\mathrm{B} 1$ fraction was more enriched in cholesterol and phospholipids than B2 and B3. Nevertheless, the cholesterol/phospholipid ratio was similar for the 3 fractions, being higher than in the homogenate or B4 fraction.

Seven classes of phospholipid were identified in membrane fractions by thin-layer chromatography (Fig. 14): diphosphatidyl glycerol, phosphatidyl 


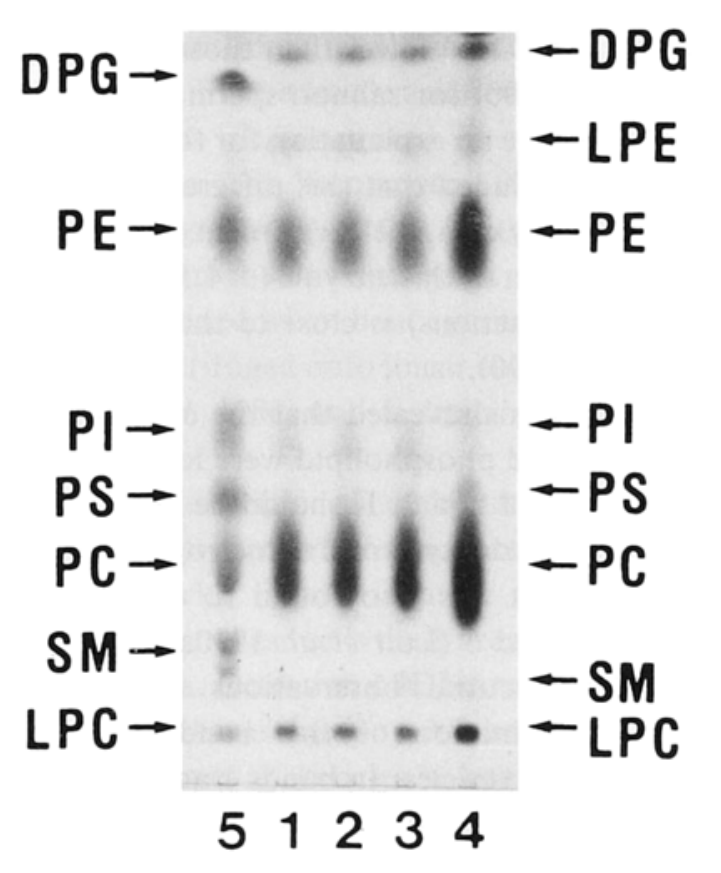

Fig. 14. Thin-layer chromatographic separation of phospholipids from, 1: membrane vesicles from band 1 obtained after nitrogen cavitation, 2: idem from band 2, 3: idem from band 3, 4: spermatozoa, 5: standards from bovine brain. LPC: Iysophosphatidyl choline, SM: sphyngomyelin, PC: phosphatidyl choline, PS: phosphatidyl serine, PI: phosphatidyl inositol, PE: phophatidyl ethanolamine, LPE: lysophosphatidyl ethanolamine, DPG: diphosphatidyl glycerol. Phospholipids were visualized by iodine vapor.

ethanolamine, phosphatidyl inositol, phosphatidyl serine, phosphatidyl choline, sphyngomyelin and lysophosphatidyl choline. Phosphatidyl ethanolamine and phosphatidylcholine were the 2 main classes of phospholipid. No difference was observed in the phospholipid composition of the 3 membrane fractions (Fig. 14). This was confirmed by preliminary quantitative data obtained after HPLC separation (Table 3 ).

\section{Discussion}

The data presented in this study show both that nitrogen cavitation is an effective method for disruption of the plasma membrane from trout spermatozoa and that 3 subsets of membranes can be isolated using linear sucrose density gradient centrifugation.
Table 3. Phospholipid composition of the 3 membrane fractions. Distribution of the five major classes of phospholipid expressed as a percentage of total phospholipid, after HPLC separation

\begin{tabular}{lcrr}
\hline & B1 & B2 & \multicolumn{1}{c}{ B3 } \\
\hline DPG & $7 \pm 5$ & $10.5 \pm 3.5$ & $7.5 \pm 3.5$ \\
PE & $31.5 \pm 2.5$ & $30.5 \pm 2.5$ & $32.5 \pm 2.5$ \\
PI & $4 \pm 1$ & $2 \pm 1$ & $2.5 \pm 0.5$ \\
PS & $8.5 \pm 3.5$ & $7.5 \pm 2.5$ & $10.5 \pm 2.5$ \\
PC & $46.5 \pm 2.5$ & $47 \pm 3$ & $47 \pm 1$ \\
\hline
\end{tabular}

Data are shown as means \pm SD $(n=2)$. DPG: diphosphatidyl glycerol; PE: phosphatidyl ethanolamine; PI: phosphatidyl inositol; PS: phosphatidyl serine; PC: phosphatidyl choline.

Since the work of Gillis et al. (1978), nitrogen cavitation has been used to prepare plasma membrane from mammalian and invertebrate spermatozoa. This method overcomes the problems associated with the use of detergent, mechanical homogenization, hypotonic shock or sonication (McNamee 1989). The yield of membrane protein following release of the plasma membrane by nitrogen cavitation was always equal or greater than $1 \%$ of the total cell protein (Gillis et al. 1978: 1\%; Mack et al. 1986: 1.6\%), i.e., according to Gillis et al. (1978) and Parks and Hammerstedt (1985) 20 to $30 \%$ of the membrane protein was obtained by this procedure.

Until the recent study of Lou et al. (1990), isolation of plasma membranes from fish spermatozoa had not been accomplished. Lou et al. (1990) prepared plasma membranes from salmon sperm by sonication, but, the recovery was only $0.6 \%$ of the total cell protein. Using nitrogen cavitation, we obtained a 3-fold higher yield for trout.

We have confirmed that nitrogen cavitation is the most effective of the methods tested. In agreement with Lou et al. (1990), we have also confirmed that it is difficult to both define the optimal conditions for sonication and to reproduce them, especially when using different sonicators.

To avoid contamination by the acrosomal membranes, a nitrogen pressure of 600-650 PSI has usually been used in the preparation of plasma membranes from mammalian spermatozoa (Noland et al. 1983). We have not examined the ultrastructural changes induced in trout sperm by 
this pressure, but protein yields and fraction compositions indicate that detachment of membrane may not be as complete and the purity not as high at 600 compared to 900 PSI. Thus, we used 900 PSI for further experiments. However, under these conditions the nuclear membrane was also partly detached.

In the majority of previous studies, plasma membrane-enriched fractions were purified from spermatozoa by discontinuous sucrose density gradient centrifugation. However, this technique may lack the resolving power to distinguish between membranes possessing subtle differences. Lou et al. (1990) used discontinuous gradients and obtained only one band in preparations of salmon sperm plasma membranes. In contrast, we obtained 3 distinct membrane bands, the mean buoyant densities of which were $1.03,1.05$ and $1.09 \mathrm{~g} / \mathrm{ml}$ respectively. These values are lower than those reported for membrane vesicles of mammalian spermatozoa (Agrawal et al. 1988, rat: $1.13 \mathrm{~g} / \mathrm{ml}$; Parks and Hammerstedt 1985, ram: $1.16 \mathrm{~g} / \mathrm{ml}$; Petersen et al. 1980, boar: $1.13-1.17 \mathrm{~g} / \mathrm{ml}$ ). Similarly, skeletal muscle plasma membranes from rainbow trout (Ablett and Selivonchick 1983) sediment at a lower density than the same membranes from rat. Ablett and Selivonchick (1983) attributed this behaviour to a high level of phospholipids which is a common feature of teleost membranes. In concordance with this, the phospholipid content of our membrane fractions was far higher ( 840 to 1920 nmoles $/ \mathrm{mg}$ protein) than that recorded for membrane vesicles from human spermatozoa (Mack et al. 1986: 82 nmoles/mg protein). The same was also true for cholesterol: 573 to $1134 \mathrm{nmoles} / \mathrm{mg}$ protein versus 68 . Furthermore, the molar ratio of cholesterol to phospholipid for trout muscle plasma membrane is half that of rat muscle plasma membranes. Similarly, for trout sperm plasma membrane we found this ratio to be $0.59-0.70$ while it is 0.83 and 0.85 in plasma membranes of human (Mack et al. 1986) and ram sperm respectively (Holt and North 1985). On the other hand, cholesterol and phospholipid contents were higher in sperm, than muscle plasma membranes of trout. This may reflect tissue differences.

The activities we measured for 5'-nucleotidase were around 7 -fold lower than those measured by Lou et al. (1990) for salmon sperm plasma membrane. We have no explanation for this, although it cannot be excluded that this difference is speciesspecific. In any case, the enrichment we obtained in the distribution of this enzyme ( $\times 4.5$ as a mean for the $\mathrm{B} 1-\mathrm{B} 3$ fractions) is close to that obtained by Lou et al. (1990).

Lipid analysis revealed that the enrichments of cholesterol and phospholipid were lower in band 3 than in bands 1 and 2 . It should be noted that the specific $20 \beta$-hydroxysteroid dehydrogenase activity (EC 1.1.1.53.) was also found to decrease from band 1 to band 3 (Loir et al. 1990a). This agrees with ultrastructural observations demonstrating some contamination of this band by material trapped in the vesicles. In bands 1 and 2 , there is a 6.3 to 6.9 -fold enrichment of cholesterol and a 4.2 to 5.4-fold enrichment of phospholipid. These values and that for 5'-nucleotidase either approach those for mammals, or, are lower (Gillis et al. 1978; Mack et al. 1986). Lower values may result from the smaller size of trout compared to mammalian spermatozoa, which implies a higher membrane protein/total cell protein ratio in fish than in mammals (there is, for instance, 5 to 10 times more protein in human (Mack et al. 1987) than in salmon (Lou et al. 1990) or trout spermatozoa). Thus, for an identical purity of the membrane fractions, the enrichment of trout sperm membrane is necessarily lower.

The size of the membrane vesicles recovered in the 3 bands was not conspicuously different. In addition, the ultrastructural appearance of the vesicles in bands 1 and 2 was identical. After SDSPAGE analysis, there is slight changes in the protein composition of membranes in the three bands. Among the proteins, the relative amount of which increases from B1 to B3, as compared to protein 42 $\mathrm{KD}$, only 2 ( 14.5 and $29 \mathrm{KD}$ ) are seminal proteins adsorbed onto the gamete surface (Loir et al. $1990 \mathrm{~b}$ ). The quantitative changes of these 2 proteins in the 3 bands could be due to partial removal during membrane preparation. However, this interpretation is not applicable to the other 11 to 22 $\mathrm{KD}$ and 26 to $32 \mathrm{KD}$ proteins. This suggests that membranes in the 3 bands have different characteristics which could reflect a lack of uniformity of 
the plasma membrane in different regions of the sperm surface. Such a local variation of the plasma membrane was demonstrated in salmon sperm surface (Haruo and Yamamoto 1984): the membrane covering the tail differs in its physiological properties from that of the head. Several bands were also obtained when boar sperm plasma membrane was centrifuged onto linear sucrose gradients (Peterson et al. 1980) and a similar interpretation was proposed.

The possible origin of membranes present in band 3 is questionable. No biochemical or ultrastructural marker could identify sperm nuclear membrane, as in these cells there are neither nuclear pores nor RNA. Detection of DNA with propidium iodide was unsuccessful (unpublished data). However, the presence in vesicles in band 3 of fibrous material which looks like chromatin fibers, on one hand, and the fact that rat liver nuclear membranes have a buoyant density slightly higher than plasma membranes (McNamee 1989) on the other, suggest that pieces of nuclear membranes could have sedimented with plasma membranes in band 3 , and maybe in band 4 .

\section{Acknowledgements}

This work was supported in part by a grant from the Institut National de la Recherche Agronomique (GCS-BBA, 1989) and by a grant from the "Region Bretagne"' (Développement de Biotechnologies appliquées à l'Aquaculture).

We thank Mr G. Maisse for helpful discussions and critical reading of the manuscript and Dr J.L. Dacheux, Dr. L. Frémont, Mrs. J. Thévenoux, Mr. A. Linard for useful advice. We are grateful to Mrs C. Cauty for her skillful assistance in electron microscopy, to J.Y. Lefeuvre for excellent assistance in preparing the figures and to J. Hall and Dr D. Webb for help with the English text. Electron microscopy was carried out at the Centre Commun de Microscopie à Transmission de l'Université de Rennes.

\section{References cited}

Ablett, R.F. and Selivonchick, D.P. 1983. The isolation of skeletal muscle plasma membranes from rainbow trout (Salmo gairdneri). Comp. Biochem. Physiol. 76B: 107-111.

Agrawal, P., Magargee, S.F. and Hammersted, R.H. 1988. Isolation and characterization of the plasma membrane of rat cauda epididymal spermatozoa. J. Androl. 9: 178-189.

Bartlett, G.R. 1959. Phosphorus assay in column chromatography. J. Biol. Chem. 234: 466-468.

Baynes, S.M. and Scott, A.P. 1982. Cryopreservation of rainbow trout spermatozoa: variation in membrane composition may influence spermatozoan survival. In Proc. Int. Symp. Reproductive Physiol. Fish. pp. 128. Edited by C.J.J. Richter and H.J.T. Goos. Pudoc, Wageningen.

Billard, R. and Jalabert, B. 1974. L'insémination artificielle de la truite (Salmo gairdneri Richardson). Il. Comparaison des effets des différents dilueurs sur la conservation de la fertilité des gamètes avant et après insèmination. Ann. Biol. Anim. Bioch. Biophys. 14: 601-610.

Cosson, M.P., Billard, R. and Letellier, L. 1989. Rise of internal $\mathrm{Ca}^{2}+$ accompanies the initiation of trout sperm motility. Cell Motil. Cytoskeleton 14: 424-434.

Dacheux, J.L., Dacheux, F. and Paquignon, M. 1989. Changes in sperm surface membrane and luminal protein fluid content during epididymal transit in the boar. Biol. Reprod. 40: $635-651$.

Damerval, C., Le Guilloux, M., Blaisonneau, J, and de Vienne. D. 1986. Coloration des proteines au nitrate d'argent: une modification de la méthode de Heukeshoven et Dernick. In Proc. 4eme Coll. Soc. Franç. Electro., Rouen.

Folch, J.M., Lees, M. and SloaneStanley, G.H. 1957. A simple method for the isolation and purification of total lipids from animal issues. 3. Biol. Chem. 226: 497-506.

Gillis, G., Peterson, R. and Russell, L. 1978. Isolation and characterization of membrane vesicles from human and boar spermatozoa: Methods using nitrogen cavitation and ionophore induced vesiculation. Prep. Biochem. 8: 363-378.

Green, D.E., Mii, S. and Kohout, P.M. 1955. Studies on the terminal electron transport system: I Succinic dehydrogenase. $J$. Biol. Chem, 217: $551-557$.

Hazel, J.R. 1984. Effects of temperature on the structure and metabolism of cell membranes in fish. Am. J. Physiol. 246: $460-470$.

Holt, W.V. and North, R.D. 1985. Determination of lipid composition and thermal phase transition temperature in an enriched plasma membrane fraction from ram spermatozoa. J. Reprod. Fert. 73: 285-294.

Jaana, H. and Yamamoto, T.S. 1984. Local variation of the cell surface in chum salmon sperm as revealed by their agglutination reaction. J. Exp. Zool. 230: 449-463.

Laemmli, U.K. 1970. Cleavage of structural proteins during the assembly of the head of bacteriophage $T_{4}$. Nature, Lond. 227: $680-685$.

Lanzetta, P.A., Alvarez, L.J., Reinach, P.S. and Candia, O.A. 
1979. An improved assay for nanomole amounts of inorganic phosphate. Anal. Biochem. 100: 95-97.

Loir, M., Labbé, C. and Vizzano, D. 1990a. Steroids in seminal fluid in the rainbow trout. In Proc. 15th Conf. Europ. Comp. Endocrinol. pp. 15.

Loir, M., Labbé, C., Maisse, G., Pinson, A., Boulard, G., Mourot, B. and Chambeyron, F. 1990b. Proteins of seminal fluid and spermatozoa in the trout (Onchorhynchus mykiss): Partial characterization and variations. Fish Physiol. Biochem. 8: 485-495.

Lou, Y.H., Yamauchi, K. and Takahashi, H. 1990. Isolation and partial characterization of sperm plasm membrane of masu salmon, Onchorhynchus masou. Comp. Biochem. Physiol. 95B: 187-192.

Lowry, O.H., Rosebrough, N.J., Farr, A.L. and Randall, R.J. 1951. Protein measurement with the folin phenol reagent. J. Biol. Chem. 193: 265-275.

Mack, S.R. and Szuchet, S. 1981. Synthesis of myelin glycosphingolipids by isolated oligodendrocytes in tissue culture. Brain Res. 214: 180-185.

Mack, S.R., Everingham, J. and Zaneveld, L.J.D. 1986. Isolation and partial characterization of the plasma membrane from human spermatozoa. J. Exp. Zool. 240: 127-136.

Maisse, G., Pinson, A. and Loir, M. 1988. Caractérisation de l'aptitude à la congélation du sperme de truite arc-en-ciel (Salmo gairdneri) par des critéres physico-chimiques. Aquat. Living Res. 1: 45-51

Malejac, M.L., Loir, M. and Maisse, G. 1990. Qualité de la membrane des spermatozoides de truite arc-en-ciel (On- chorhynchus mykiss). Relation avec l'aptitude du sperme à la congélation. Aquat. Living Res. 3: 43-54.

McNamee, M.G. 1989. Isolation and characterization of cell membrane. Biotechniques 7: 466-475.

Michell, R.H. and Hawthorne, J.N. 1965. The site of diphosphoinositoside synthesis in rat liver. Biochem. Biophys. Res. Commun. 21: 333-346.

Morisawa, S. and Morisawa, M. 1988. Induction of potential for sperm motility by bicarbonate and $\mathrm{pH}$ in rainbow trout and chum salmon. J. Exp. Biol. 136: 13-22.

Noland, T.D., Olson, G.E. and Garbers, D.L. 1983. Purification and partial characterization of plasma membranes from bovine spermatozoa. Biol. Reprod. 29: 987-998.

O'Farrell, P.H. 1975. High resolution two-dimensional electrophoresis of proteins. J. Biol. Chem. 250: 4007-4021.

Parks, J.E. and Hammerstedt, R.H. 1985. Developmental changes occurring in the lipids of ram epididymal spermatozoa plasma membrane. Biol. Reprod. 32: 653-668.

Peterson, R., Russell, L., Bundman, D. and Freund, M. 1980. Evaluation of the purity of boar sperm plasma membranes prepared by nitrogen cavitation. Biol. Reprod. 23: 637-645. Smith, P.K., Krohn, R.I., Hermanson, G.T., Mallia, A.K., Gartner, F.H., Provenzano, M.D., Fujimoto, E.K., Goeke, N.M., Olson, B.J. and Klenk, D.C. 1985. Measurement of protein using bicinchoninic acid. Anal. Biochem. 150: 76-85.

Watanabe, T., Takeuchi, T., Saito, M. and Nishimura, K. 1984. Effect of low protein-high calory or essential fatty acid deficiency diet on reproduction of rainbow trout. Bull. Jap. Soc. Scient. Fish. 50: 1207-1215. 